\title{
Diversion of Excess Water in Badulu Oya for Augmentation of Loggal Oya Reservoir for Generation of Hydropower (Concept Paper)
}

\begin{abstract}
A.K.D.N. Atukorala
Abstract: With the implementation of Uma Oya Multipurpose Diversion Project, part of Uma Oya water will be diverted to the Kirindi Oya basin to compensate for the water shortages in the south-east dry zone. As a result the water received presently at Rantambe from Uma Oya will be reduced approximately by one third. Badulu Oya which joins the Malaweli Ganga downstream of Uma Oya flows underneath the Minipe Right Bank (RB) canal. Hence major part of the water in Badulu Oya at present flows to Mahawel Ganga without being made use. Further, there is certain potential energy in the water of Badulu Oya and adjacent Loggal Oya which can be converted to electrical energy by augmenting the water source of Minipe RB canal. The objective of this article is to identify the most probable means to investigate the possibilities of harnessing both water resource and hydropower potential in the two streams.
\end{abstract}

Keywords: Baduluoya, Loggaloya, Minipe right bank canal, diversion

\section{Introduction}

Badulu Oya which originates from Namunukula hills traverses approximately 40 $\mathrm{km}$ before it reaches Mahaweli Ganga. The total catchment area of Badulu Oya is $318 \mathrm{~km}^{2}$ and annual average rainfall of the catchment area is $2000 \mathrm{~mm}$. Mean stream flow is $12 \mathrm{~m}^{3} / \mathrm{s}$. The Badulu Oya anicut which is located approximately $16 \mathrm{~km}$ upstream of the confluence with Mahaweli Ganga provides water for irrigation of 1017 ha of agricultural land. The diversion through the Kandaketiya irrigation canal is approximately $2.5 \mathrm{~m}^{3} / \mathrm{s}$. Hence the balance $9.5 \mathrm{~m}^{3} / \mathrm{s}$ of the mean flow discharges to the Mahaweli Ganga without being used.

Similarly part of the Loggal Oya water is discharged to the Mahaweli Ganga during flash floods as there is no sufficient storage capacity in the existing level crossing reservoir of the Minipe RB canal. The concept of this article is to review the water resources in these two basins in order to provide supplementary flow to the Minipe RB canal on an effective and economical manner. Loggal Oya has a catchment area of $199 \mathrm{~km}^{2}$ and an annual average rainfall of 2400 mm with a mean stream flow of $10.3 \mathrm{~m}^{3} / \mathrm{s}$.

\section{Historical Background}

An anicut has been built across Badulu Oya in year 1948 about $16 \mathrm{~km}$ upstream of the confluence with Mahaweli Ganga with a $13 \mathrm{~km}$ canal on the right bank to convey $2.5 \mathrm{~m}^{3} / \mathrm{s}$ to command 1017 ha of agricultural land. A mini hydro power station has been built by the private sector upstream of this anicut.

A level crossing reservoir was constructed in 1984 under the Accelerated Mahaweli Development Program across Loggal oya to command part of water in the Loggal Oya. As it was only a level crossing reservoir it does not have sufficient storage capacity for storing excess water during the rainy season and hence the excess water spills over to the Mahaweli Ganga.

\section{Need of a New Concept}

At present approximately $9.5 \mathrm{~m}^{3} / \mathrm{s}$ of annual average flow of Badulu Oya discharges in to Mahaweli Ganga without making any use while the farmers under Badulu Oya anicut

Eng. A.K.D.N. Atukorala, C. Eng., MIE(Sri Lanka), MICE(UK), B.Sc. Eng. (Hons), DHE(Delft)

Deputy Project Director (Engineering)

Uma Oya Multipurpose Development Project

Ministry of Irrigation and Water Resource Management 
suffer water shortage in months of August and September. This quantity of water is approximately $300 \mathrm{MCM}$ which is more than double the water quantity expected to be diverted from Uma Oya to Kirindi Oya basin. If part of this water can be directed to the Minipe RB canal then the loss of water from Uma Oya can be compensated from Badulu Oya. Also at the same time, augmenting existing water supply from Badulu Oya anicut during dry weather period is also possible.

Hence it is very important to regulate all available water resources in the upstream area to get the maximum benefit for the people in an economical manner.

A new concept should be adopted which should necessarily imply that more water shall be diverted to the Minipe RB canal by construction of storage reservoirs in Uma Oya in order to fulfil the future requirements.

\section{Study Option}

Depending on the present developments in the area and considering the topography of the area, constructing large reservoirs in the Badulu Oya basin is not feasible. Hence the only possibility is to divert water to the RB canal using a weir and in a suitable conveyance route. One option for transferring water to the RB canal would be constructing a contour canal starting from a suitable location to suit the level of the RB canal in the proximity. The size of the open canal for transferring $9.5 \mathrm{~m}^{3} / \mathrm{s}$ would be considerably larger and this will damage large area of existing fertile agricultural lands.

The most appropriate and the best solution would be the construction of a weir across Badulu Oya downstream of the existing anicut and divert water to the Loggal Oya level crossing reservoir and thereby augmenting the RB canal. The river bed at existing anicut consists of exposed sound bed rock and hence would be an ideal location for a weir or a dam. Construction of a high dam for a large storage reservoir is not possible due to the existing mini hydro powerhouse constructed upstream of the anicut.

The elevation of the existing anicut across Badulu Oya is approximately at $161 \mathrm{msl}$ and the full supply level of Loggal Oya level crossing reservoir is at $111 \mathrm{msl}$. The level difference between two locations which is approximately $50 \mathrm{~m}$ could be used to generate $34 \mathrm{GWh}$ annually while water is diverted to RB canal. If suitable arrangements are made this energy can be produced during the peak hours of electrical energy consumption and thereby minimise the use of expensive thermal power plants.

The adjacent Loggal Oya basin carries 10.3 $\mathrm{m}^{3} / \mathrm{s}$ mean flow to the Loggal Oya reservoir. If this water is also routed through the power plant which could be located on the left bank of the existing Loggal Oya reservoir, this water will produce another 38 GWh of electrical energy which could be connected to the national grid. Building a suitable storage reservoir on the Loggal Oya basin could save some of the water which spills over the Loggal Oya level crossing reservoir during flash floods and thereby can regulate the utilisation of water in Loggal Oya for agriculture.

Many options cannot be considered in this work as the areas have been substantially developed and hence only the most suitable option is described here.

\section{Proposed Project Components}

After analysing all possible combinations with selected alternatives, the following combination which is given in the schematic diagram was found to be the most economical among all other alternatives. The selected layout of this proposal is shown in the Attachment 1. The principal components of the best combination are as follows.

\subsection{Badulu Oya Diversion}

Major component of the diversion scheme is a weir across Badulu Oya downstream of the existing anicut. As the water supply to the existing irrigation canal needs to be given priority, the level of the intake to the future diversion shall be selected above the existing anicut level to guarantee the present discharge under any circumstances after constructing the new structures. A tunnel approximately $6400 \mathrm{~m}$ long on the right bank of Badulu Oya will convey the water to the Loggal Oya reservoir. This will have the least social and environmental impact from the proposed construction. This weir will eliminate the existing water shortages during the months of August and September in the irrigable area fed by Kandaketiya existing canal. 


\section{2}

\section{Loggal Oya Reservoir and Powerhouse}

A storage reservoir could be constructed in the upstream of the existing reservoir approximately at elevation $160 \mathrm{msl}$ and connecting this reservoir to the headrace tunnel of Budulu Oya diversion tunnel with a $2300 \mathrm{~m}$ long tunnel. The length of the dam will be approximately $1000 \mathrm{~m}$ which is about $25 \mathrm{~m}$ high at river section and constructed with earthfill.

Water from both rivers could be directed through one powerhouse located on the left bank of existing Loggal Oya reservoir and the installed capacity of this power plant will be decided based on the operational pattern of the power plant.

\section{Benefits}

More than $300 \mathrm{MCM}$ of water which goes to the sea through Mahaweli Ganga at present flows from Badulu Oya and Loggal Oya. This water will be diverted for the benefit of the people who will receive water through the Minipe RB canal. In addition to this, another $72 \mathrm{GWh}$ of electrical energy will be added to the national grid through this development.

The employment opportunities for the unemployed youth in and around project area will be enhanced significantly and a number of new jobs will be created during the project construction period. With the development of the area more direct and indirect employment opportunities will also be created. Thus the project will generate considerable employment opportunities and will have a great impact on economic growth in Sri Lanka. In addition to the direct benefits various secondary and intangible benefits and favourable socioeconomic impacts could also be expected by implementation of the project.

\section{Impact on Existing Water Users}

There are no major irrigation schemes which use water from the downstream of the Badulu Oya anicut. The required downstream flow for environmental and for any riparian farmers will be released through the weir. Underground water conveyance system (tunnels) has been selected to avoid the impact to the existing agricultural lands and to minimise the construction cost.
Few agricultural lands will be inundated for the proposed reservoir on Loggal Oya. Either compensation or new land could be provided for the affected people.

\section{Conclusion}

According to this concept approximately 300 MCM of additional water could be added annually from the combination of Badulu Oya and Loggal Oya to augment water users in the existing schemes both in Yala and Maha seasons. This will wipe out the effect of construction of Uma Oya project which will divert part of its water to the Kirindi Oya basin. Further, the releases from the Mahaweli system to Minipe Right Bank canal could be reduced and this water could be used to transfer water through the proposed Left Bank canal to supply water to the proposed NCP canal. In this process approximately $72 \mathrm{GWh}$ of electrical energy could also be generated annually with a power plant having an installed capacity of 20 MW.

In formulating the above concept the information and data available was limited. Therefore more accurate information for hydrological and topographical data should be collected for fine tuning of the project. I consider that the Government of Sri Lanka will take an initiative to make a thorough study on this proposal and if it is found to be feasible then expect construction to commence without delay.

\section{Reference}

1. Arumugam, S. Water Resources of Ceylon, 1969. 
Schematic Diagram of Proposed Diversion of Badulu Oya for Augmentation of Loggal Oya Reservoir for Generation of Hydropower

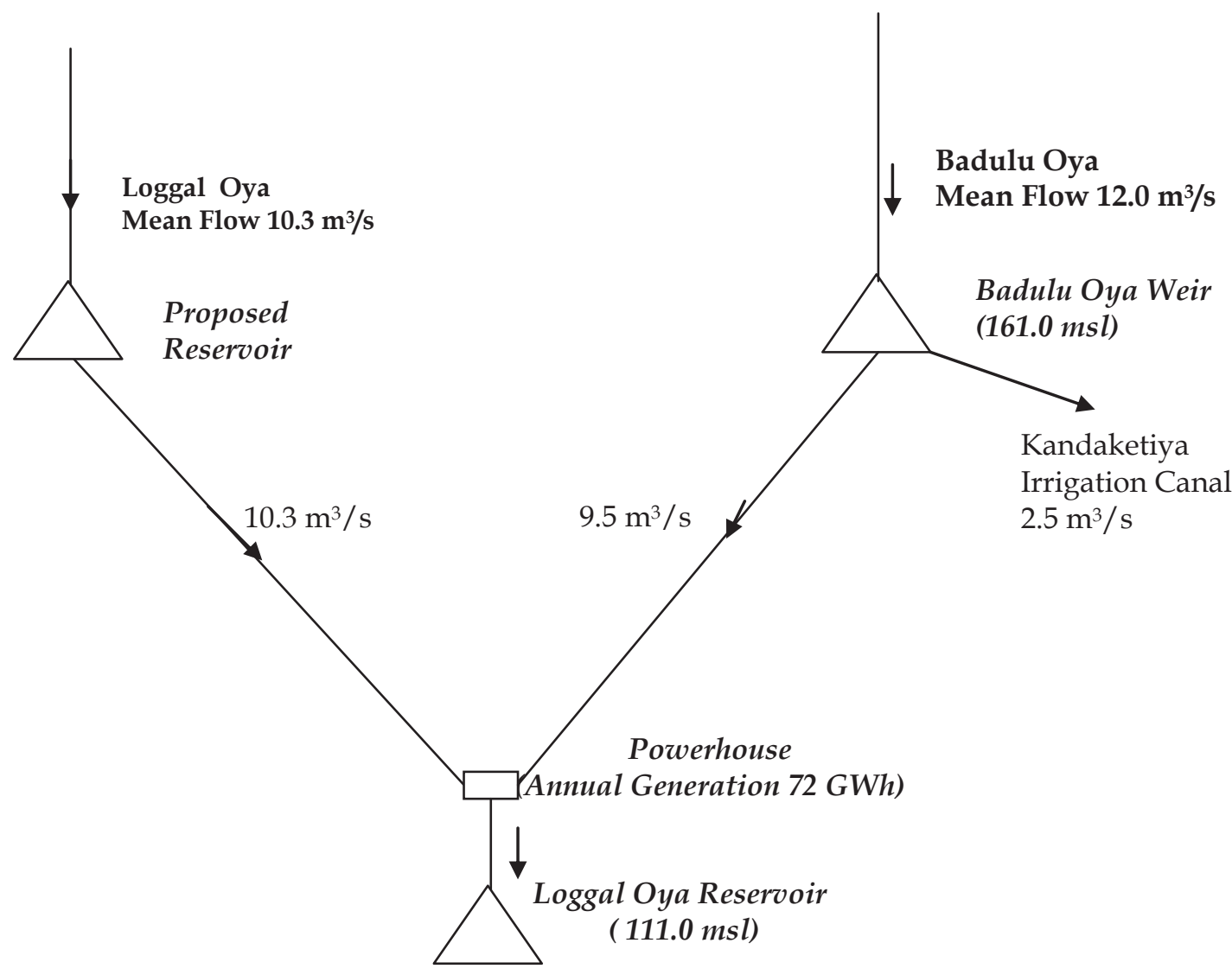

